\title{
BREAKING THE AUTOBIOGRAPHICAL PACT: TRUTH AND LIFE-WRITING IN ALISON BECHDEL'S FUN HOME
}

\author{
MARÍA ELENA CARPINTERO TORRES-QUEVEDO \\ University of Edinburgh \\ mariaelenactq@gmail.com
}

Received 12 April 2020

Accepted 1 December 2020

KEYWORDS: truth, graphic novel, Bildungsroman, coming-of-age, fiction, memoir, autobiography, family, queerness, authenticity

PALABRAS CLAVE: verdad, novela gráfica, Bildungsroman, novela de aprendizaje, ficción, memorias, autobiografia, familia, queerness, autenticidad

ABSTRACT: Much of the focus on truth in critical responses to Fun Home has surrounded the use of archival evidence and the access to truth provided by the graphic medium. This article will explore these issues as well as the relationship to truth established by the text's metafictional devices and interactions with genre, particularly the genre of the Bildungsroman. This article will analyze the commentary the text provides not just on its own relationship to truth, but the role of truth in autobiographical texts in general, and in women's and other marginalized groups' autobiographical texts in particular. In the context of a critical landscape in which the veracity of autobiographical work by women is often subject to skeptical criticism, this article will argue that Fun Home acts, not as an exception to the genre of autobiography, but as a commentary on the gap between the presumed autobiographical pact and the historical, political, and aesthetic reality of autobiographical works.

RESUMEN: Gran parte del enfoque en la verdad en las respuestas críticas a esta novela se ha basado en el uso de evidencia de archivo y el acceso a la verdad proporcionado por el medio gráfico. Este artículo explorará estos problemas, así como la relación con la verdad establecida por los dispositivos metaficcionales del texto y las interacciones con el género, particularmente el género del Bildungsroman. Este artículo analizará los comentarios que proporciona el texto no solo sobre su propia relación con la verdad, 
sino también sobre el papel de la verdad en los textos autobiográficos en general, y en los textos autobiográficos de las mujeres y otros grupos marginados en particular. En el contexto de un panorama crítico en el que la veracidad del trabajo autobiográfico de las mujeres a menudo está sujeta a críticas escépticas, este artículo argumentará que Fun Home actúa, no como una excepción al género de la autobiografia, sino como un comentario sobre la brecha entre presunto pacto autobiográfico y la realidad histórica, politica y estética de las obras autobiográficas.

Alison Bechdel's graphic memoir, Fun Home: A Family Tragicomic (2006) follows Alison on a non-linear trajectory from childhood into adulthood. The text is heavily rooted in the generic conventions of the coming-of-age story, the Künstleroman, and the coming-out story. I will refer here to the author as Bechdel and the subject and narrator of the narrative as Alison. The narration of Alison's life focuses on her father's monumental influence over her and his untimely death. The narrative voice is predominantly that of adult Alison, though the focalization is often shifted to a younger version, while the drawings are mostly of young Alison, a contrast that sets up a meta-self-representation in line with the selfconsciousness of the text as a whole. Alison's story, heavy with intertextual references and other metafictional devices, is a meditation not just on the development of her own queer and artistic identity, but also of her father's. The latter, Alison discovers as an adult, has a sexual preference for young men. Alison describes his femininity and his propensity for "artifice" as his defining traits, which frequently clash with her own masculinity, preference for the austere and functional, and attachment to notions of authenticity and truth. Bechdel portrays their cohabitation and family dynamics throughout her childhood, their connection through literature during her adolescence and college years, and her discovery and exploration of her sexuality-which is quickly followed by her discovery of his sexuality-and his death, which she assumes to be an act of suicide. Throughout the story, Alison fastidiously presents and analyzes archival evidence, invokes historical events, and filters her descriptions through literary allusions and other metafictional devices.

Despite its graphic content-there are a number of scenes portraying sex, masturbation, and corpses-Fun Home has been both 
commercially and critically successful; it is taught on a number of university courses, and it has been made into a Broadway musical. The representation of "truth" within the text has been the object of significant studies. Robin Bernstein focuses on the marketing of Bechdel's work and her drawing process, reading the image as a way to represent truth during the Bush administration: "Bechdel published a book about reality and truth at a moment when these entities became objects of urgent public critique [...] Fun Home and the word 'truthiness' harmonize as critical responses to Bush-era modes of meaning making" (132-4). Jeremy D. Popkin similarly argues that "in an age all too prone to assume that memory, with its emotional appeal and its link to fiction, is more important to human life than the factual record, projects like these reassert the value of a more critical view, even of the personal past" (137). Also, Chute described the text as one "not about what happened, but about ideas about what happened, arrived at through archives" (180).

My interpretation of Fun Home focuses on the text's concern with the relationship between truth and fiction, played out through meditations on history and identity and their rootedness in textuality. It is worth noting that, while Fun Home is described by critics as an autobiography and a memoir, these terms are not used in the title, subtitle, or any of the other paratexts, with the exception of quotes from reviews on the cover. In fact, the paratextual generic designation provided is "A Family Tragicomic." This is significant in many ways, not least because it emancipates the text from the burden of truth described by Lejeune's "autobiographical pact." While there has been significant scholarship arguing against the implicit referentiality of autobiography, the expectation of truth on behalf of readers is still present, as confirmed by cases of demonstrably false autobiographies like that of James Frey. Fun Home itself vacillates between claims of absolute veracity and selfconscious meditations on the reliability, or lack thereof, of its composition and narration.

Bechdel's embedding of her story in the conventions of the Bildungsroman is particularly notable because the story is a memoir. Memoir is perhaps the perfect genre in which to trouble the lines of fiction and non-fiction, being simultaneously a genre so indebted to and deeply rooted in fictional conventions, and a "non-fiction" genre in which the "truth" is considered paramount. Bechdel draws attention to this tension both through her self-conscious signaling of her use of coming-of-age tropes and intertextual references to other 
Bildungsroman, and through her own construction of herself as an unreliable narrator. While Bechdel does not explicitly call the text a memoir in her own paratextual matter, Alison notes her "own compulsive propensity towards autobiography," (140) and a number of the reviews chosen for the book cover label it a memoir. These factors are notable because they serve to emancipate the text from the strict truth demands of the memoir whilst still allowing it to reference the memoir and comment on the genre and its parameters. This disavowal of the truth demands of the memoir is repeated through references to the "roman à clef" (201), a genre focusing on the "real life" of the author beneath a façade of fiction. The relationship that Bechdel establishes between fiction and non-fiction, and the genres of the Bildungsroman and the memoir in particular, is a particularly productive one; it creates a lens through which to understand the ways in which fiction and "reality" are related to each other, and the role that power has in this relationship. The analysis of this perspective is arguably a much more salient and critically useful contribution to the genre of the memoir than any evaluation of the "truthfulness" of the account would be.

This article will read Fun Home primarily in relation to the generic conventions of autobiography, analyzing how Bechdel troubles the fiction and non-fiction distinction and reveals the politics implicit in genre. I will look at Bechdel's use of intertextuality, visual remediation, and generic references to the Bildungsroman as tools through which to establish a relationship to the "truth pact" of autobiography. I argue that Bechdel disturbs the truth pact through depictions of Alison's authorial anxiety and its attendant social and literary repressions. Contrary to several previous studies, I argue that what Fun Home presents is not a nostalgia for truth or authorial control, but an exploration of the relationship between subjectivity, art, and power.

One of the most frequently noted characteristics of Fun Home is its incessant self-conscious intertextual references; the chapters are named after lines from canonical literary works, and the text opens with a chapter named after the last line in James Joyce's $A$ Portrait of the Artist as a Young Man (1916), with the first few frames introducing Alison's relationship with her father through a convoluted Icarus and Daedalus reference. Hillary Chute suggests that this is one of the elements that has elevated the novel's status above the majority of graphic novels, stating that "one of the reasons that Fun Home may have been so quickly accepted as serious 
literature is that it is explicitly 'literary': it discusses, and cites, many famous, mostly modernist, works of literature at length" (185). Indeed, a claim to authority is one of the multiple functions of the invocation of canonical works. Julia Watson notes that "[i]n probing the intersection of popular media with the grand narrative of high modernism, Bechdel troubles the assumed boundaries of literary canons, and slyly suggests that inverting literary and sexual hierarchies works to liberate energies for this new, twenty-firstcentury moment of autographic creation" (305). Through these invocations, Bechdel suggests that a marginalized literary form-the graphic novel-is as worthy of critical attention as the modernist novel. Furthermore, Bechdel associates the story of a subject belonging to a number of marginalized groups as a young, queer girl, to the authority provided by modernist literature. Her narrator makes these connections explicit when she says: "I embarked that day on an Odyssey which, consisting as it did in a gradual, episodic, and inevitable convergence with my abstracted father, was very nearly as epic as the original" (203). Bechdel's narrative repeatedly insists on the equivalence of her experiences to those traditionally represented in Western literature. Beyond the authority this provides, it also familiarizes a story about a marginalized subject; it appropriates the narratives of canonical Western protagonists to express a story of queerness, rendering it accessible.

It quickly becomes clear that these literary allusions are not merely a way for the author to establish authority or elicit empathy. For the narrator, these literary allusions serve as a filter through which to understand her own experiences. She comments repeatedly on her father's preference for fiction over reality, noting "I think what was so alluring to my father about Fitzgerald's stories was their inextricability from Fitzgerald's life" (65) and that "[i]n a way Gatsby's pristine books and my father's worn ones signify the same thing-the preference of a fiction to reality" (85). The second quotation is particularly significant in that it signals Alison's own investment in fiction; she describes her father, and indeed the majority of her experiences, through literary references and terms. She, like her father, cannot meaningfully separate fiction and reality, indeed, she describes the way fiction conditions her understanding of her reality explicitly: "my parents were most real to me in fictional terms" (67). Furthermore, the text's meaning is constructed in part through deferral to other texts. For example, in an episode to which Alison refers as her and her father's "Ithaca moment" (222), a college-aged 
Alison and her father discuss their shared experience of growing up homosexual and identifying with the opposite gender. The caption meditates on the significance of this passage, noting "[i]t was not the sobbing, joyous reunion of Odysseus and Telemachus. It was more like fatherless Stephen and sonless Bloom" (221). This narration signals the mood of this episode by deferring to both The Odyssey and James Joyce's Ulysses (1918), and positioning Alison's narrative in relation to these. While Alison's story and perspective are arguably too far removed from those she invokes for any authentic identification, there is an authenticity that accrues from the way in which she engages with them; her identification is made real by the social context in which it is employed. The interweaving of intertextual references with Alison's own life functions not just to legitimate a story that risks being marginalized along with its subject, but to problematize the separation of life-writing and fiction through an exposition of the way fiction conditions the construction and understanding of the self.

Notably, despite her own repeated literary allusions and recourse to fictional conventions, young Alison associates fiction and art with her father, and this association is contemptuous. In fact, she repeatedly implies that her father's love of the arts is directly related to his status as a closeted homosexual. She uses terms like "artifice" (16), "legerdemain" (5), and "embellishment" (16) to imply an inextricable relationship between her father's art and inauthenticity or lying. Regarding his refurbishment of their worn down Victorian house, Alison pronounces him "[a]n alchemist of appearance, a savant of surface, a Daedalus of decor" (6), and says he would "spin garbage in gold" (6), likening him to the repulsive antagonist of children's stories Rumplestiltskin. To young Alison, art is a small step away from artifice. She describes their house as "not a real home at all but a simulacrum of one" (17), and claims her father was invested in her family predominantly because of "the air of authenticity we lent to his exhibit" (13). She links this inauthenticity to his sexuality in particular in a frame showing the dictionary definition of "queer," with the words "suspicious" and "counterfeit" highlighted (57). Furthermore, she relates his love of adornment and its accompanying duplicitousness to his femininity, which she contrasts to her own sincerity and masculinity, referencing her "own decided preference for the unadorned and purely functional emerged early" (14) in a caption above a frame of teenage Alison expressing her disgust for the flowery, embellished room she has been forced to 
help her father decorate. A few pages later, as she describes their domestic ornaments, she would say: "If anything, they obscured function. They were embellishments in the worst sense. They were lies" (16), furthering her association between femininity and deception.

Alison's distaste for her father's perceived inauthenticity is deeply ironic. She narrates her contempt for what she sees as his insincerity woven into her disgruntled feelings about his love of adornment in what is a rather insincere move since the episodes in which she relates feeling this resentment occurred before she knew he was hiding anything at all. The equivalence she establishes between her father's aesthetic pursuits and his sexual pursuits occurs much later, and could not have influenced her emotions at the time that it appears to do so in the text. This is adult Alison's artistic license in play in a way that the young version that she constructs of herself would heavily disapprove of. Furthermore, many of her descriptions of Bruce's adornments of the house are laden with literary allusions, which are themselves a form of artistic embellishment. Indeed, she even refers to her use of them as providing her with "aesthetic distance" (67). Moreover, she is telling all of this not only in the form of literature but through illustration, in particular an illustrated narrative about her own identity as a lesbian and as an artist. The faults that Alison finds in Bruce and through which she tries to distance herself from him--namely, his coterminous homosexuality, inauthenticity, and artfulness--are qualities that are inextricable from the self that she constructs through her narration.

As Alison comes-of-age, her binary feelings about authenticity and artifice dissipate and are replaced with a more complex worldview. In a frame discussing her father's restored library, the narrating Alison acknowledges that "perhaps affectation can be so thoroughgoing, so authentic in its details, that it stops being pretense" (60). The concept of authenticity, a concept often central to autobiographical texts, becomes the object of suspicion and irony. This is mirrored in some of the literary allusions such as Alison's mother taking a central role in a production of Oscar Wilde's The Importance of Being Earnest (1895). It is worth noting that this is a text about homosexuality taking place under the protective screen of stereotypical heterosexual relationships, but it is also a text that celebrates artifice; it mocks the very notion of authenticity and rejects the possibility of it in a restrictive heteronormative society. 
Indeed, Alison finds that artifice reveals as much as it conceals. What she finally resents is not her father's love for aesthetics, but what the politics of her father's aesthetics are. The problem with his romanticization of big embellished manors and his enforcement of femininity on Alison is not the gayness it reveals in him, but the nostalgia and the commitment to the heteropatriarchal nuclear family he harbors in spite of his sexuality.

While the adolescent obsession with truth that the adult Alison projects onto the younger Alison's feelings about her father are problematic, young Alison goes through a period of truth-related anxiety with regards to her self. Bruce encourages Alison to start a diary when she is on the cusp of adolescence, while she is suffering from obsessive-compulsive disorder. He even writes the first few words down for her. Initially, she uses her diary to record the events of her everyday life. However, she notes, she soon begins to insert the word "I think" between her sentences. She comments on this behavior, affirming, "It was a sort of epistemological crisis. How did I know that the things I was writing were absolutely, objectively true? All I could speak for was my own perceptions, and perhaps not even those. My simple, declarative sentences began to strike me as hubristic at best, utter lies at worst" (141). She begins to use these interventions so often that she develops a shortcut: drawing a circumflex over particular words, then sentences, and eventually entire pages, which she believes to be "warding off evil from my subjects" (142). Pearl interprets this as a linguistic crisis, asserting: "Words are so fraught and unreliable that young Alison develops a disorder that requires her to insert into her adolescent writing symbols that undermine the authority of her written observations and recollections and feelings" (292). Alison undermines her own authority in so far as she believes that authority to be predicated on her ability to provide the truth. However, her struggle for authority is not merely a struggle with language. The young Alison has a sense of the autobiographical pact even in her personal diary, and she finds the obligation to present the truth an impossible burden, not because she cannot find the words to convey the truth or reality, but because she is not even convinced of her ability to know it.

Alison struggles with a literary form that demands truth in part because she does not identify with the artistic productions that she has been set as examples, and in part because she has never experienced anyone like herself writing with any authoritative stance on the truth. Cynthia Barounis frames Alison's diary entries, 
informed by her disorder, in the context of a literary history of "madwomen" as conceptualized by Virginia Woolf and Gilbert and Gubar. She discusses Woolf's belief that the "disfiguring power of feminist anger" (140) diminishes women's ability to write, as well as Gilbert and Gubar's belief in female "madness" as "a powerful expression of feminist rage" (141) that is undermined by the madwoman's silencing. Barounis notes how, in contrast to these frequent tropes of female mental illness, Bechdel "performs a subtle inversion of Woolf's dismissal of disability and mental illness as the mark of artistic failure" (144). Though her anxiety resembles Gilbert and Gubar's anxiety of authorship, Barounis argues that Alison does not suffer from the lack of any artistic antecedents with which to identify because of her own "butch identification with (and complicated affection for) her effeminate father" (145). While these are all valuable insights, I argue that Alison's anxiety of authorship, though expressed through her obsessive-compulsive disorder, is primarily an anxiety that develops as a result of her similarity with her father. While Alison does at times identify with her father, the parts of him with which she identifies are parts that he suppresses and lies about; his artistic pursuits are all ones that express a nostalgia for a strict, Victorian, patriarchal and heterosexual past. In this sense, she has no artistic precursors and he acts as a patriarchal authority. In an episode in which Alison is coloring in a Wind in the Willows coloring book, her father comes and corrects her selection of color, replacing her blue with the "canary yellow" described in the novel (130). Furthermore, her obsessive-compulsive disorder does not, as Barounis suggests, enable her to produce art, and she finds her obsession with the truth and her failure to access it so overwhelming, that she stops writing altogether for a period of time (149).

The concept of truth is also key to Bernstein's interpretation of Fun Home, which she reads in the context of the Bush administration:

As Bechdel frequently laments in her serialized comic strip Dykes to Watch Out For, the Bush presidency posited truth as unknowable, facts as infinitely flexible, and faith as constitutive of reality. Fun Home never mentions the president (nor any historical figure or event after the mid-1980s), but the memoir uses newly available digital technology to resist Bush-era 'truthiness' (121). 
The term "truthiness," which was coined by professional satirist of right-wing politicians Stephen Colbert, refers to "the belief in what you feel to be true rather than what the facts will support" (The Late Show, $\mathrm{np}$ ). This is a particularly salient interpretation in the political climate of the late 2010s, often labeled the "post-truth" era, defined by the OED as a culture in which "objective facts are less influential in shaping public opinion than appeals to emotion and personal belief" (OED). Both the Bush administration during which Fun Home was written and the Trump administration have been marked by a right-wing appropriation of poststructuralist discourse. Kellyanne Conway's claim of "alternative facts" (NBC News, np) invokes both Jean François Lyotard's belief that truths should be plural and local, and Michel Foucault's concept of "subjugated knowledges" or "le savouir des gens," defined as "knowledges, located low down on the hierarchy, beneath the required level of cognition or scientificity [...] unqualified, even directly disqualified knowledges [...] a particular, local, regional knowledge, a differential knowledge incapable of unanimity" (82). Both Bush-era truthiness and the post-truth era highlight the dangers of eschewing the notion of truth altogether, exposing how easily people can be swayed by arguments that tap into social anxiety, regardless of conflicting evidence; it seems to confirm what many have long believed: that postmodernism as a discourse appropriates the concept of marginalization whilst doing nothing for those that are actually marginalized.

A common suggestion amongst critics is that Alison resolves her truth-related anxiety through her drawing, because drawing gives her greater access to the truth than language can approximate. Valerie Rohy has argued that in the novel, "[t]he word seems figural where the image is literal, fictional where the image is factual, abstract where the image is concrete. And indeed, in Fun Home the visual reproduction of objects seems to offer an authenticity beyond the power of rhetoric, a potential to signify what 'really happened' " (351); Robyn Warhol asserts that "Fun Home itself is the corrected version of Alison's journal. Where she had left holes marked with the "curvy circumflex," Fun Home fills in with pictures." (10). Pearl argues that "[t]he drawings prove rather than apologize for or excuse the veracity of her words" (294); and Robin suggests that "in [Dykes to Watch Out For], Bechdel's characters bemoan Bush's assault on reality, but in Fun Home, Bechdel counters it. She does so by combining comics, her body in performance, and a technology that was then newly available to the masses: digital photography" (134). 
The digital photography refers to the fact that Bechdel states in a number of interviews that she poses for photographs, which act as models for each frame that she draws. There is a common sentiment that the visual elements of Alison's narrative give her greater ability to represent the truth than language does, and in this sentiment, there is the assumption that the purpose of Alison's story is to represent the truth. Indeed, Elizabeth El Refaie argues that "[b]y deliberately diverging from the stylistic conventions associated with more traditional, fantastical comic book genres, the creators of autobiographical comics can stress the truthful nature of their accounts" (138).

I argue, however, that neither Alison nor Bechdel find any greater approximation to truth in drawings. Digital photographs of Bechdel posing for drawings that will be of Bruce, for example, do not approximate those drawings any closer to authenticity or truth than any drawing she could do from her imagination. Furthermore, she still has full control over the construction of the frame and the illustration. While this technique may be a handy tool in creating verisimilitude in her human figures, it bears no relation to truth in any meaningful way. Alison, likewise, uses drawings to represent the world as she constructs it in her imagination. In an episode in which she is retelling a story her grandmother told her about her father getting stuck in mud as a child and having to be rescued by a mailman, Alison illustrates the frame with a picture of a milkman, with a textbook stating: "(I know Mort was a mailman, but I always pictured him as a milkman, all in white-a reverse grim reaper" (41). Rather than finding a way to access and represent the truth, Alison finds in drawing a liberation from the burden of representing absolute, objective truth. While the diary or the autobiography are genres that historically come with a burden of truth, cartoons, comics, and illustration do not carry that same burden. Astrid Erll discusses the importance of "unintentional and implicit ways of cultural remembering [...] or of inherently non-narrative, for example visual or bodily, forms of memory" (2) in creating cultural memory. These forms do not have a privileged relationship to the truth, but they do offer different ways of communicating the experiences of others. Other writers of autobiographical graphic novels have employed the freedom provided by the form to circumnavigate the demands of the genre. For example, Art Spiegelman in Maus: A Survivor's Tale (2003), a memoir composed of his father's recollections of his survival of the Holocaust and the interviews that 
lead to those recollections told in the form of the graphic novel, draws his characters with cat or mouse heads, depending on whether they are Jewish or Nazis, and yet, as Nancy Miller notes, his account was listed as non-fiction by the New York Times (539). Julia Novak argues that this technique "is a highly effective way to visualise the vulnerability of Holocaust victims vis-à-vis their tormentors" (3-4), lending more emotional veracity through fictionalisation. For Alison, then, drawing is a way to represent and embrace her subjectivity; she does not need to deface her drawings with the disclaimer "I think," because drawing is already understood to be a subjective pursuit, representing the artist's truth rather than an absolute, universal truth.

The freedom from "truth" that Alison experiences through the development of her artistic talents develops as she matures through adolescence into adulthood. Initially, she admits uncertainty regarding some of the events that she reports, which is particularly significant because her interpretations of those particular events underlie her entire narrative. She comments, "there's no proof, actually, that my father killed himself" (27), though the next piece of text claims, "no one knew it wasn't an accident" (27). Alison's assumption of her father's suicide is key to the construction of her narrative and her self-understanding, with much of the text dedicated to the social and political circumstances that lead him to suicide, and those that enable her to live. Nevertheless, the truth of even this fundamental event is called into question, not because Alison is lying, but because she has constructed her text and her identity on an event about which she can never be certain. Furthermore, she admits that, despite her crucial identification with her father being their shared homosexuality, he never told her as much explicitly, stating "I shouldn't pretend to know what my father's [erotic truth] was" (230). Nevertheless, she does on the very next page, where she suggests, over an illustration of her father and herself that "spiritual, not consubstantial, paternity is the important thing" (231), reclaiming once again the shared bond about which she has just revealed uncertainty.

The concurrence of Alison's maturation and unreliability is notable and significant. She affirms that her period "passed unmentioned in [her] diary" (59), and suggests a correspondence between the innocence of youth and the pressure to represent objective truth in writing. She writes that her "diary was no longer the utterly reliable document it had been in my youth. A faltering, 
elliptic tone was creeping in" (162); and "as I aged, hard facts gave way to vagaries of emotion and opinion" (169). After an episode in which Alison and her female friend miss their school dance in favor of cross dressing, which she describes as a "mystical pleasure" (182), she describes her record of the events in her diary: "my profession of disappointment at missing the game and dance was an utter falsehood, of course" (183), and "my narration had by this point become altogether unreliable" (184). A little later, when she finally tells her mother that she has been getting her period for months, she notes "my diary entries had given way to the implicit lie of the blank page, and weeks at a time are left unrecorded" (186). These episodes establish a relationship between Alison's coming of age and an increased propensity to construct her story according to principles other than "truth." The development of Alison's sexuality and the loss of her innocence are both connected via an increased awareness of the criteria outlined by culturally sanctioned narratives, and the particular ways in which her own narrative as a queer girl does not conform to those narratives, or the ways in which she does not want those narratives to dictate her identity. As such, she omits information that she does not feel prepared to process or internalize, she misreports her sentiments to conform to what she knows she should feel, and she begins to focus more on her interior life than her exterior life.

The progression Alison marks in her narrative from youth, innocence, and a desire for "truth" through adolescence to a more mature, compromised, and compromising position is one that takes place regularly in the Bildungsroman, particularly in the American Bildungsroman. Indeed, the youthful obsession with adult phoniness and authenticity is so prevalent that it is almost generically determined. It can be traced back to Huck Finn's comments about the hypocrisy of adults, through Holden Caulfield's angst about being "surrounded by phonies" (13) in The Catcher in the Rye and Esther Greenwood's similar concerns in The Bell Jar (1963), to more contemporary texts such as Josephine Humphreys' Rich in Love (1987), Bobbie Anne Mason's In Country (1985), and Sandra Cisneros' The House on Mango Street (1984). This change in epistemic position with the development of sexuality is often coterminous with a fall from innocence in a manner reminiscent of the Book of Genesis. This, again, is a relationship that Alison picks up on and explicitly draws from. During a trip to the woods with her father, Alison accesses pornography for the first time through the 
calendar of one of her father's friends, and she describes her response in biblical terms: "I felt as if I'd been stripped naked myself, inexplicably ashamed, like Adam and Eve" (112). This incident leads her to pretend to be a boy around her father's friend for the rest of the weekend. She goes on to prove incapable of pulling the trigger of her father's gun, a task he insists he could do at her age, which is immediately followed by her sighting of a large snake (114). She concludes this episode lamenting: "On the drive home, a postlapsarian melancholy crept over me. I had failed some unspoken initiation rite, and life's possibilities were no longer infinite" (115). The disappointment she feels stems from the knowledge of the social meaning of her gender and sexuality, which she becomes aware of due to the literal and symbolic events of the weekend. Her association between these experiences and the discourse of the coming-of-age genre, with terms such as "initiation rite" and the reference to the fall of man, are intentional metafictional devices that root her narrative in the legacy of the American Bildungsroman.

There are further thematic generic markers. Alison's obsession both with her parents as origin and her desire for emancipation, expressed through her assertion: "I had imaged my confession as an emancipation from my parents, but instead I was pulled back into their orbit" (59) and that "[m]y father's end was my beginning" (117), her father's literal beginning of her diary, and her father as the beginning of Fun Home, are all prevalent in the Bildungsroman. In his book, Coming of Age in Contemporary American Fiction (2007), Kenneth Millard discusses the centrality of a sense of history and origins in the genre:

The form and structure of these novels is often strongly expressive of a desire to create a myth of origins by which their protagonists can come to understand themselves, and this knowledge, despite a selfconsciousness about its status as fiction, is a central component of coming of age. (9)

This is a particularly salient lens through which to read Alison's representation of her father. Her aforementioned mythologizing of him is the product of a generically grounded desire to locate an antecedent and a myth of origins in a narrative about identity construction. She describes her discovery of his homosexuality as an "abrupt and wholesale revision of my history" (79 emphasis added), and imagines the life he would have had had he lived as one in which 
he would have died of AIDS. She notes, "perhaps I'm being histrionic, trying to display my actual grief with this imaginary trauma [...] Or maybe I'm trying to render my senseless, personal loss meaningful by linking it, however posthumously, to a more coherent narrative" (195-6). Indeed, she draws comparisons between the trajectory of her own life and large cultural events regularly. For example, she claims: "This juxtaposition of the last days of childhood with those of Nixon and the end of that larger, national innocence may seem trite, but it was only one of many heavy-handed plot devices to befall my family during those strange, hot months" (155). She also tenuously connects a childhood memory of visiting New York to the Stonewall riots, with the disclaimer: "I acknowledge the absurdity of claiming a connection to that mythologized flashpoint" (104). The desire Alison expresses for the teleologically rational, coherent, and culturally recognizably narrative of the American Bildungsroman is perhaps all the more marked because of the marginal social position that she occupies. Notably, she draws on this mythologizing of origins selfconsciously, drawing attention repeatedly to the fact that the connections she is making to her father and historical events, much like the connections she makes to particular texts, are tenuous, problematic, and somewhat inauthentic. In doing this, she is signaling not just the myth of origins she wishes to construct, but the fact that she feels the need to construct it. She is not merely repeating the generic marks of the Bildungsroman, but highlighting them and commenting on them.

Alison regularly refers to various Bildungsromane in both text and illustration, including $A$ Portrait of the Artist as a Young Man, Rubyfruit Jungle, and The Catcher in the Rye; indeed, Alison's father tells her of A Portrait of the Artist as a Young Man that she "damn well better identify with every damn page" (201), and asks her "When are you going to read Catcher in the Rye?" (198), and she goes on to describe him teaching that same text to his high school students. The reference to The Catcher in the Rye is doubly metafictional in that, not only is it a reference to a canonical Bildungsroman, but references to it are so frequent in more contemporary coming-of-age stories, that it is almost a cliché [Igby Goes Down (2002), The Perks of Being a Wallflower (1999)]. In fact, Phoebe Gloeckner's The Diary of a Teenage Girl: An Account in Words and Pictures, another semiautobiographical graphic novel published in 2005, about a young girl's relationship with an adult man, with similar themes of pedophilia, has an almost identical scene to Bechdel's high school 
English class on Salinger's novel, with the same focus on Mr. Antolini. This once again emphasizes the centrality of canonical works to Alison's self-understanding and self-construction; in particular the influence of the Bildungsroman, although the pressure to identify with certain perspectives that are very alien to her experience comes largely from her father. When she goes to college, she moves her textual focus outside of the white male bounds imposed by her father and the canon, turning instead to literature with a focus on lesbianism. Indeed, she describes her lesbianism "a revelation not of the flesh, but of the mind" (74), and titles the text in which she comes out after a line from Colette (207). Her identity remains very much conditioned by the narratives she encounters, even if those narratives become more emancipated from a heteronormative, patriarchal authority.

However, even this apparent emancipation from her father and patriarchal authority is generically determined. Not only are many of the episodes Alison includes as central to the construction of her identity generically determined, theyare fictionally determined. Unless we accept the naturalization of adolescence in the form it takes in American fiction, the way Alison's story so closely follows and poignantly deviates from the traditional American Bildungsroman is highly suspicious. I do not mean to suggest here that any of the particular events or sentiments she reports are not rooted in the reality of her life--a fact which is unknowable and not particularly useful from a critical standpoint--but that there is a certain amount of artifice, embellishment, or artistic license that takes place here. Alison's self understanding is clearly heavily influenced by the fictional paradigm of American coming-of-age, whether in the way she interprets her experiences as they happen, or the way she makes sense of them after the fact. Her story is not some untampered, "authentic" record of the "true" facts of her life, but a construction deeply conditioned by her understanding of a set of narrative codes that give the events in her life meaning and cultural weight. Furthermore, Bechdel's decision to encode the narrative of the development of a lesbian identity in the trappings of the Bildungsroman is significant. Not only does she employ the form of assimilation that I mentioned in my introduction to this article, wherein the conventions of mainstream established fictional genres are deployed to present marginalized experiences and perspective through a familiarizing lens. She also comments on the politics of the traditional Bildungsroman through her difficulty in locating her 
experiences in it and the artificiality with which she has to establish the teleology implicit in the genre.

One of the ways in which Bechdel resists the politics of the Bildungsroman while working within it is through her use of time and space. The traditional American Bildungsroman relies on a linear chronology to inform the teleological development of the protagonist, with events positioned in cause-and-effect relationships and a logical and arguably even deterministic life trajectory. As previously mentioned, a number of critics have commented on Bechdel's atypical use of time; the story of Alison's coming of age is not told through a linear chronology, but through what Pearl describes as "a layered telling, adding information and impressions over the story as it has already been told" (289). Marjorie C. Allison addresses this feature by commenting that: "traditional Western art and literature don't wander much. On the whole, we're a pretty goaloriented culture. But, in the East there's a rich tradition of cyclical and labyrinthine works of art" (75). However, Bechdel's chronology might be better understood through the lens of Halbertstam's concept of queer time. Halberstam asserts that "[q]ueer uses of time and space develop, at least in part, in opposition to the institutions of family, heterosexuality, and reproduction" (12), and defines queer time as "specific models of temporality that emerge within postmodernism once one leaves the temporal frames of bourgeois reproduction and family, longevity, risk/safety, and inheritance" (20). Alison's story rejects the normative temporal logic of the female Bildungsroman in a number of ways; firstly, she avoids the usual initiation rites of teenage girls in fiction, opting instead for masculinized initiation rites, which, as previously mentioned, she fails. Elaine Hoffman Baruch, in her article "The Feminine Bildungsroman: Education Through Marriage" (1981), argues that the female Bildungsroman tends to depict development happening later in life to adult women via or resulting in marriage. She states that "women [...] have turned to marriage to achieve the goals of romantic individualism, those of increased knowledge, enhancement of feeling and experience" (340). While Alison's story is about her sexuality in many ways, it entertains this only as an aspect of her identity, rather than centering on her romantic possibilities and the reproductive and familial futures determined therein. In the novel, there is never any entertainment of marriage or motherhood, a concern that is central to many women's coming-of-age narratives. To the extent that she does follow the time/space conventions of the 
Bildungsroman, she does so in ways that reject heteronormativity; she employs the escape trope of the Bildungsroman to escape, both physically and symbolically, the hetero-patriarchal repression of small-town American life that her father suffered, and which she blames for his death. She even shows a map of the area to which her father confined his life, an atemporal map with past and future houses coexisting, and states that: "I'd kill myself too if I had to live here" (125), drawing a comparison between geographic and psychological stasis and entrapment. Unlike her father, Alison escapes the town and the model of development prescribed by the bourgeois value of the nuclear family.

Furthermore, Alison does not follow the narrative arc of childadolescent-adult in a strict, linear fashion. Even as she struggles to construct an origin story for herself that gives her identity coherence, teleological legitimacy, and the acceptance and authority implicit in these, Alison's narrative rejects the chronology of causality. As mentioned above, she attributes feelings to herself before she could have had the information required to have them; she describes her father's death as "not a new catastrophe but an old one that had been unfolding very slowly for a long time" (83) and claims that "[h]is absence resonated retroactively, echoing back through all the time I knew him" (23). Furthermore, hypotheticals, episodes from literature, and mutually exclusive events all form a part of her narrative. On the last two pages, she wonders: "What if Icarus hadn't hurtled into the sea? What if he'd inherited his father's inventive bent? What might he have wrought? [...] He did hurtle into the sea of course, but in the tricky reverse narration that impels out entwined stories, he was there to catch me when I leapt" (231-232). She undermines her attempts to construct linearity and causality by presenting effects that take place before their causes, and sentiments that occur anachronically. In rejecting the kind of deterministic temporality implicit in the traditional Bildungsroman, she rejects a causality that, within a heteronormative society and literary paradigm, can only be heteronormative. Indeed, not only is this causality heteronormative, it also casts everything that came before it in the light of the projected end - a falsely determined reality that starts to seem inevitable to those who accept it. Alison avoids constructing a story that revolves around locating the "cause" of the "effect" of being queer in favor of writing about the experiential reality of existing as a queer woman in a particular context within American history and geography. Alison's narration does organize events in terms of theme, 
their effect on her, or their role in her self-understanding, but avoids implications of a predetermined outcome and the essentialism that would accompany it. In this sense, she simultaneously adopts the generic form of the Bildungsroman to render the story of a liminal subject familiar, while resisting the repressive and oppressive politics of its conventions.

Bechdel's frequent references to fictional texts, particularly Bildungsromane, her employment of fictional devices, and her references to fictional generic conventions in her construction of a text implicitly understood as a representation of her "truth" works in part to render visible the ways in which fiction and truth can be blurred. These allow Bechdel to explore how fictional conventions determine the interpretation and organization of self and identity. In Genre (2006), John Frow argues that "genres actively generate and shape knowledge of the world; [...] generically shaped knowledges are bound up with the exercise of power, where power is understood as being exercised in discourse [...] far from being merely 'stylistic' devices, genres create effects of reality and truth, authority and plausibility, which are central to the different ways the world is understood" (2). Bechdel's employment of the conventions of the Bildungsroman, then, exposes the power dynamics of the genre. Generic conventions certainly are central to the way that Alison understands the world, specifically those of the Bildungsroman and the memoir; indeed they serve as a central and conditioning influence on her life and her self. Importantly, though, these genres fail to fully house Alison or her story because they have been historically dominated by white, male, and heterosexual authors and hence have conventions that are inherently tied to the representation of a white, male, heterosexual subjectivity and models of development. Her textual marginalization mirrors her sexual marginalization, and her "reality" and "truth" do not align with the cultural expectations that she has been provided with by this literary education. Her deviations from the generic conventions of the Bildungsroman and the memoir highlight the difficulty of constructing a coherent, teleological identity through the terms, chronologies, and tropes of these male-centered genres, and in doing so highlight the marginalization of stories about people and experiences more closely aligned with Alison.

One could argue that the Bechdel's distancing of her text from the label "memoir" and her rejection of the autobiographical pact render the use of these genres as a lens through which to read 
the text invalid. Indeed, the text deviates significantly from the generic demands of the memoir. However, it still invokes the genre and participates in it. The commentary that Fun Home provides on truth, literature, and identity construction is dependent on the reader's knowledge and understanding of the generic rules of lifewriting. Alison's anxiety about her ability to tell the truth, her obsessive deferral to archives, and her comments on the ultimate unknowability of the "truth," the inaccessibility of an authentic self prior to cultural and textual conditioning, and the innately inauthentic nature of art, all work together to undermine the autobiographical pact altogether as they rely on the text being read as autobiographical in order to do so.

The autobiographical pact is one that is disproportionately burdensome for writers from marginalized communities. Not only do these writers often find their work ghettoized or suffer from a greater demand for "authenticity" (in the form of culturally recognizable stereotypes) in their texts, but the experiences they represent often engender hostility from readers outside their communities. Such hostility can arouse suspicion and discrediting. Leigh Gilmore, writing about testimony, a genre in which an individual from a marginalized community tells their own story of marginalization to highlight the wider marginalization of their community, argues that "the function of 'I' in testimonio enables one person to stand in for the collective. Yet even as the 'I' connotes a plural eyewitness, a hostile audience can substitute the test that someone is or is not telling the truth as the criterion of judgement for that testimonio" (Tainted Witness 14). A similar situation can be located in other forms of life-writing; the representation of the oppression of one subject can be used to elucidate wider societal and structural problems. In these situations, the autobiographical pact functions as a tool with which to discredit not just the veracity of the author's story, but by extension, the veracity of the societal and structural problems to which it refers. While the "truth" of any memoir is all but impossible to verify, it is not used as a tool to undermine the wider philosophical statements of Thoreau's Walden (1854), St Augustine's Confessions, or similar texts. Gilmore goes on to state that "the thesis that a witness is either telling the truth or lying functions as a proxy for veiling the conversation of the power to judge" (15). The autobiographical pact is not a critical tool for the analysis of lifewriting, but the affirmation of the critic's power to dismiss the lifewriting of the less powerful. 
Alison's adolescent abandonment of "truth" is not a corruption in the way the generic conventions of the Bildungsroman dictate; rather, it is a liberation. I do not mean to suggest that Bechdel's memoir is a lie, but that she claims artistic license to tell her story and emancipates herself from the generic imposition of the autobiographical pact and the power dynamics through which it is used. John Frow, with regard to the "effects of reality and truth, authority and plausibility" (2) that he ascribes to genres, affirms that "these effects are not, however, fixed or stable, since texts - even the simplest and most formulaic-do not 'belong' to genres but are, rather, uses of them" (2). Indeed, through Fun Home, Bechdel appropriates and subverts the generic forms of the Bildungsroman and the memoir to disturb the ways in which the Bildungsroman conditions our understanding of reality and truth and the ways in which the memoir constructs the illusion of reality and truth, and uses these as a tool with which to undermine the stories of marginalized subjects. The text works to transform these genres from within, making space for the stories of other marginalized subjects.

\section{WORKS CITED}

Allison, Marjorie C. "(Not) Lost in the Margins: Gender and Identity in Graphic Texts." Mosaic: a Journal for the Interdisciplinary Study of Literature 47.4, 2014, pp. 73-97.

Barounis, Cynthia. "Alison Bechdel and Crip-Feminist Autobiography." Journal of Modern Literature 39.4, 2016, pp. 139-161.

Baruch, E. H. "The Feminine Bildungsroman: Education through Marriage." Massachusetts Review 22, 1981, pp. 335-57.

Bechdel, Alison. Fun Home: A Family Tragicomic. London, Jonathan Cape, 2006.

Bernstein, Robin. "I'm Very Happy to Be in the Reality-Based Community': Alison Bechdel's Fun Home, Digital Photography, and George W. Bush." American Literature 89.1. 2017, pp. 121-154.

Boldrini, Lucia \& Novack, Julia, editors. Experiments in Life-Writing. Intersections of Auto/Biography and Fiction. London: Palgrave Macmillan, 2017. 
Chute, Hillary L. Graphic Women Life Narrative and Contemporary Comics. Columbia University Press, 2010.

El Refaie, Elizabeth. Autobiographical Comics. Life Writing in Pictures. Jackson: University Press of Mississippi, 2012.

Erll, Astrid, and Nünning, Ansgar. Cultural Memory Studies. Walter De Gruyter GmbH Co.KG, 2010.

Foucault, Michel, and Colin Gordon. Power/Knowledge : Selected Interviews and Other Writings, 1972-1977. Harvester Press, 1980.

Frow, John. Genre. Routledge, 2006.

Gilmore, Leigh. Tainted Witness: Why We Doubt What Women Say About Their Lives. Columbia University Press, 2017.

Halberstam, Judith. In a Queer Time and Place: Transgender Bodies, Subcultural Lives. New York University Press, 2005.

Lejeune, Philippe. Le Pacte Autobiographique. Éditions Du Seuil, 1996.

Lyotard, Jean-François. "Excepts from The Postmodern Condition: A Report on Knowledge." A Postmodern Reader. Edited by Linda Hutcheon and Joseph P. Natoli. State University of New York Press, 1993, pp. 71-90.

Millard, Kenneth. Coming of Age in Contemporary American Fiction. Edinburgh University Press, 2007.

Miller, Nancy K. "The Entangled Self: Genre Bondage in the Age of the Memoir." PMLA 122. 2, 2007, pp. 537-548.

NBC News. "Kellyanne Conway: Press Secretary Sean Spicer Gave 'Alternative Facts' | Meet the Press | NBC News". Interview with Kellyanne Conway. YouTube, 22 Jan 2017, https://www.youtube.com/watch?v=VSrEEDQgFc8.

Oxford English Dictionary. "post-truth, adj." OED Online, Oxford University Press, July 2018, www.oed.com/view/Entry/58609044. Accessed 10 September 2018.

Pearl, Monica B. “Graphic Language.” Prose Studies 30.3, 2008, pp. 286304. 
Popkin, Jeremy D. "Family Memoir and Self-Discovery." Life Writing, 2015, $1-12$.

Rohy, Valerie. "In The Queer Archive: Fun Home." GLQ: A Journal of Lesbian and Gay Studies, vol. 16, no. 3, 2010, pp. 341-361.

Salinger, J.D. The Catcher in the Rye. Boston: Little, Brown and Company, 1991.

The Late Show with Stephen Colbert. "'Post-Truth' Is Just A Rip-Off of 'Truthiness" YouTube, 18 Nov 2016, https://www.youtube.com/watch?v=Ck0yqUoBY7M

Warhol, Robyn. "The Space Between: A Narrative Approach to Alison Bechdel's Fun Home." College Literature 38.3, 2011, pp. 1-20.

Watson, Julia. "The Pleasures of Reading in Alison Bechdel's Fun Home." Life Writing 9.3, 2012, pp. 303-314.

\section{Intertexts Referenced}

Bechdel, Alison. Dykes to Watch Out For. 1983-2008.

Brown, Rita Mae. Rubyfruit Jungle. 1983.

Chbosky, Stephen. The Perks of Being a Wallflower. 1999.

Cisneros, Sandra. The House on Mango Street. 1984.

Fitzgerald, F. Scott. The Great Gatsby. 1925.

Gloeckner, Phoebe. The Diary of a Teenage Girl: An Account in Words and Pictures. 2002.

Grahame, Kenneth. The Wind in the Willows. 1908.

Homer. The Odyssey. $8^{\text {th }}$ Century BC.

Humphreys, Josephine. Rich in Love. 1987.

Igby Goes Down. Directed by Burr Steers. 2002.

Joyce, James. A Portrait of the Artist as a Young Man. 1916.

--. Ulysses. 1918. 
Mason, Bobbie Anne. In Country. 1985.

Plath, Sylvia. The Bell Jar. 1963.

Salinger, J.D. The Catcher in the Rye. 1951.

Spiegelman, Art. Maus: A Survivor's Tale. 2003.

Wilde, Oscar. The Importance of Being Earnest. 1895. 